\title{
SISTEM PENDUKUNG KEPUTUSAN PEMILIHAN CALON WALI NAGARI MENGGUNAKAN METODE TOPSIS
}

\author{
Dodi Guswandi ${ }^{1)}$, Musli Yanto ${ }^{2)}$. \\ ${ }^{1}$ Ilmu Komputer, Universitas Putra Indonesia "YPTK" Padang \\ email: guswandidodi@upiyptk.ac.id \\ ${ }^{2}$ Ilmu Komputer, Universitas Putra Indonesia "YPTK" Padang \\ email: musli_yanto@upiyptk.ac.id
}

\begin{abstract}
Abstrak
Pemilihan calon Wali Nagari merupakan sebuah kegiatan yang dilakukan oleh masyarakat dengan melakukan aktifitas pemungutan suara untuk menentukan pemimpin dalam sebuah kenagarian yang ada di daerah. Calon Wali Nagari itu sendiri atau yang setingkat dengan kelurahan merupakan seorang yang dipercaya dalam memimpin masyarakat di suatu kawasan atau daerah. Dalam menentukan pemilihan calon wali nagari, adapun penelitian ini menggunakan sebuah konsep Sistem Pendukung keputusan (SPK) dengan metode TOPSIS. Sistem pendukung keputusan yang dibangun ini dapat memberikan rekomendasi pilihan kepada masyarakat terhadap calon Wali Nagari yang akan memimpin dimasa yang akan datang. Metode TOPSIS yang digunakan dapat melakukan sebuah perhitungan yang dimulai dengan menentukan kriteria dari variabel yang digunakan, kemudian menciptakan matrik dan dilanjutkan pada proses matriks solusi lalu pada akhirnya proses akan masuk pada tahap perangkingan hingga keluaran yang dapat merekomendasikan calon Wali Nagari yang terbaik untuk dapat memimpin masyarakatnya pada periode selanjutnya. Hasil yang didapat dalam penelitian juga memberikan sebuah model ataupun bentuk sistem yang semi tersruktur dalam penentuan calon Wali Nagari menggunakan sistem pendukung keputusan metode TOPSIS. Sehingga manfaat yang akan dapat adalah memberikan rekomendasi kemudahan bagi masyarakat untuk memilih calon Wali Nagari secara tepat dan akurat.
\end{abstract}

Keywords: Wali Nagari, perangkingan, Sistem Pendukung Keputusan, Metode Topsis

\section{INTRODUCTION}

The change of village government to the Nagari government in West Sumatra province was held again in 2001. The aim is the implementation of government by the characteristics of the people of West Sumatra who are indigenous peoples [1]. In its implementation, to organize and take care of the interests of the community in Nagari, a Nagari government consisting of Wali Nagari and Bamus Nagari was formed. The organizational structure and governance of Nagari and Bamus Nagari are regulated by district/city regulations. Members of Bamus Nagari consist of elements Ninik Mamak (indigenous figures/chiefs), Alim Ulama (Religious Leaders), Cadiak
Pandai (scholars), Bundo Kanduang (Women Leaders) and other components of society that grow and develop in Nagari concerned with considering the representation of village set using deliberation and consensus [2]. The birth of Law No.23 of 2014 became the basis for the birth of Law No.6 of 2014 on Villages, it further strengthened the status of the village as a government that has genuine and democratic autonomy rights. The birth of this village law became the legal basis for the simultaneous selection of village chiefs in Indonesia, as stated in Article 31 paragraph (1) [3].

The implementation of Pilwana with the E-Voting system provides convenience for the public in voting, and the possibility of potential fraud is smaller 
than the voting system by the paper [4]. Changes in political behavior are increased public participation compared to previous years, High levels of public awareness using their motivated suffrage and people's voter behavior are influenced by sociological factors such as ethnic similarities between voters and their chosen people, increased public participation compared to previous years, High levels of public awareness using their motivated suffrage and people's voter behavior influenced by sociological factors such as ethnic similarities between voters and people they choose [5].

Decision problems are not only caused by uncertainty or imperfection of information, the variety of selection criteria, and also the weight value of each criterion is a form of very complex decision problems. Today, multicritical problem-solving methods have been widely used in various fields. One method that can be used to solve multicritical problems is the Technique For Order Preference by Similarity to Ideal Solution (TOPSIS) [6].

Based on the explanation above and the lack of a system that can help the community in recommending the selection of trustees, it is necessary to build a decision support system using the Technique For Others Reference by Similarity to Ideal Solution (TOPSIS) method that will help and facilitate the community in choosing Wali Nagari quickly and accurately.

Based on previous research as a reference source in this research, one of them is the application of AHP-TOPSIS fuzzy to rank the number of microfabrication manufacturing processes, the purpose of this study was to rank additive manufacturing (AM) for microfabrication using fuzzy analytic hierarchy process (AHP)-a technique for order of preference by similarity to ideal solution (TOPSIS) Selection of AM technology formulated as a multi-criteria decision making problem (MCDM) and ranking obtained by using fuzzy AHPTOPSIS Five candidates considered are laser-induced forward transfer (LIFT), micro stereolithography, micro-SLS, inkjet, 3D microprinting [7].

Another research is The Decision Support System for Determining Tourist Locations with TOPSIS Method, the research aims to build a decision support system (SPK) for the determination of tourist locations by TOPSIS and fuzzy methods. This method will give weighting criteria according to the user's condition/ preferences, and then process the data that is flavorful/fuzzy. TOPSIS method will provide an alternative ranking that ensures proximity to benefit criteria and keep it away from cost criteria. System implementation is done using the MySQL database and PHP language. Spk built can produce recommendations by giving the role of tourist locations to users according to their preferences [8].

Other research is Credit Scoring Debtor Feasibility Using Hybrid Ann Backpropagation and TOPSIS Method. SPK with JST backpropagation is used to classify prospective debtors who are accepted and also who are rejected based on previously established criteria. As for improving accuracy in decision making, this research will also be dihybrid using TOPSIS (Technique for Order of Preference by Similarity to Ideal Solution) method. The TOPSIS method is used to find priorities by sorting by ranking so that it can be looked back at the most important priorities before making a final decision [9].

Decision Support System (DSS) 
Decision Support System is a specific information system intended to assist management in making decisions related to semi-structured issues. The system has the facility to produce a variety of alternatives that are interactively used by the user [10].

The decision support system is a system that can be interactively in decision making through user data and decision models to solve problems that are semi-structured and unstructured. Decision making must be objective in decision making [11]. Characteristics of the decision support system are [12]:

a. Support the decision-making process of an organization or company.

b. The existence of a human/machine interface where human beings (users) still hold control of the decisionmaking process.

c. Supports decision making to discuss structured, semi-structured issues and supports multiple decisions that interact with each other.

d. Have the capacity of dialogue to obtain information as needed.

e. It has an integrated subsystem in such a way that it can serve as a unitary system.

f. It has two main components namely data and model.

There are three basic components of a decision support system (DSS) [13]:

a. Database management system (DBMS). DBMS serves as a data bank for DSS. It stores a large amount of data relevant to the problem class that the DSS has designed and provides the logical data structure (as opposed to the physical data structure) that users use to interact. DBMS separates the user from the physical aspects of the structure and processing of the database. It should also be able to member information to users about the types of data available and how to get access to that data.

b. Base management system (MBMS) model. The role of MBMS is analogous to the role of DBMS, its main function is to provide independence among certain models used in the DSS of the application that uses it. The purpose of MBMS is to convert data from DBMS into useful information in decision making. MBMS should also be able to assist users in building models.

c. Generation and management system (DGMS) dialog. The main product of interaction with DSS is insight. Since its users are often computer-trained people, DSS needs to be equipped with an intuitive and easy-to-use interface. This interface helps in building models, but also in interactions with models, such as gaining insights and recommendations from them. The primary responsibility of DGMS is to improve the ability of system users to utilize and benefit from DSS.

The interaction between the three basic components is illustrated in the image below:

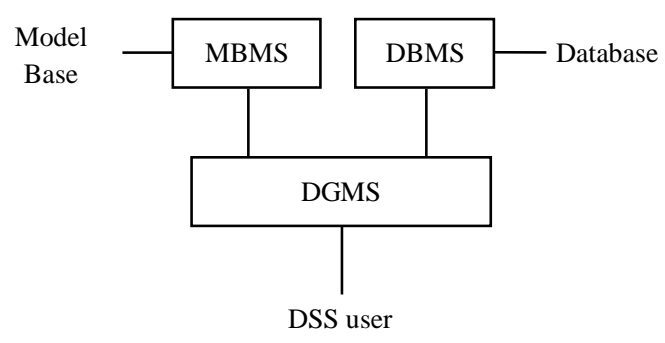

Figure 1: Decision Support System Components

\section{The Technique for Order Preference by Similarity to Ideal Solution (TOPSIS)}

TOPSIS stands for Technique for Order Preference by Similarity to Ideal Solution. TOPSIS is a method that uses 
the principle that the chosen alternative must have the closest distance from the ideal solution positive and furthest from the negative ideal solution. This method is widely used to complete decision-making practices. This is because the concept is simple and easy to understand and efficient and can measure the relative performance of decision alternatives [14].

In general, the TOPSIS procedure follows the following steps [15]:

1. Create a normalized decision weight matrix. TOPSIS requires performance rating of every Ai alternative at every normalized Rij weight, namely:

$$
r i j=\frac{X_{i j}}{\sum_{i}^{m} X_{i j}^{2}}
$$

Where:

$\mathrm{Xij}=$ Matrix of prospective employee assessment input data with $\mathrm{i}=1,2,3, \ldots$ $\mathrm{m}, \mathrm{j}=1,2,3, \ldots \mathrm{N}$.

rij $=$ matrix normalization criteria assessment with $\mathrm{i}=1.2, \ldots \mathrm{M}$.

$\mathrm{m}=$ number of prospective employees.

$\mathrm{n}=$ number of assessment criteria.

$\mathrm{A}+$ positive ideal solution and $\mathrm{A}$ - the negative ideal solution can be determined based on normalization weight ranking ( Yij ):

$$
\begin{aligned}
& y_{i j}=w_{j} r_{i j} \\
& A^{+}=\left(y_{1}^{+}, y_{2}^{+}, \ldots y_{n}^{+}\right) \\
& A^{-}=\left(y_{1}^{-}, y_{2}^{-}, \ldots y_{n}^{-}\right) \\
& y_{j}^{+}=\max y_{i j} \\
& y_{j}^{-}=\min y_{i j}
\end{aligned}
$$

2. Calculate alternate distances.

The distance between ai alternatives and positive ideal solutions is formulated:

$$
D_{i}^{+}=\sqrt{\sum_{j=1}^{n}\left(y_{i}^{+}-y_{i j}\right)^{2}}
$$

The distance between $\mathrm{Ai}$ alternatives and the ideal negative solution is formulated:

$$
D_{i}^{-}=\sqrt{\sum_{j=1}^{n}\left(y_{i}^{-}-y_{i j}\right)^{2}}
$$

3. Specify the value of the preference.

Preference value for each alternative (Vi) given.

$$
V i=\frac{D_{i}^{-}}{D_{i}^{-}+D_{i}^{+}}
$$

The greater $\mathrm{Vi}$ value indicates that the $\mathrm{Ai}$ alternative is preferred.

\section{RESEARCH METHODS}

To guide the preparation of this research, it is necessary to have a clear framework structure (Frame Work) stages, as follows:

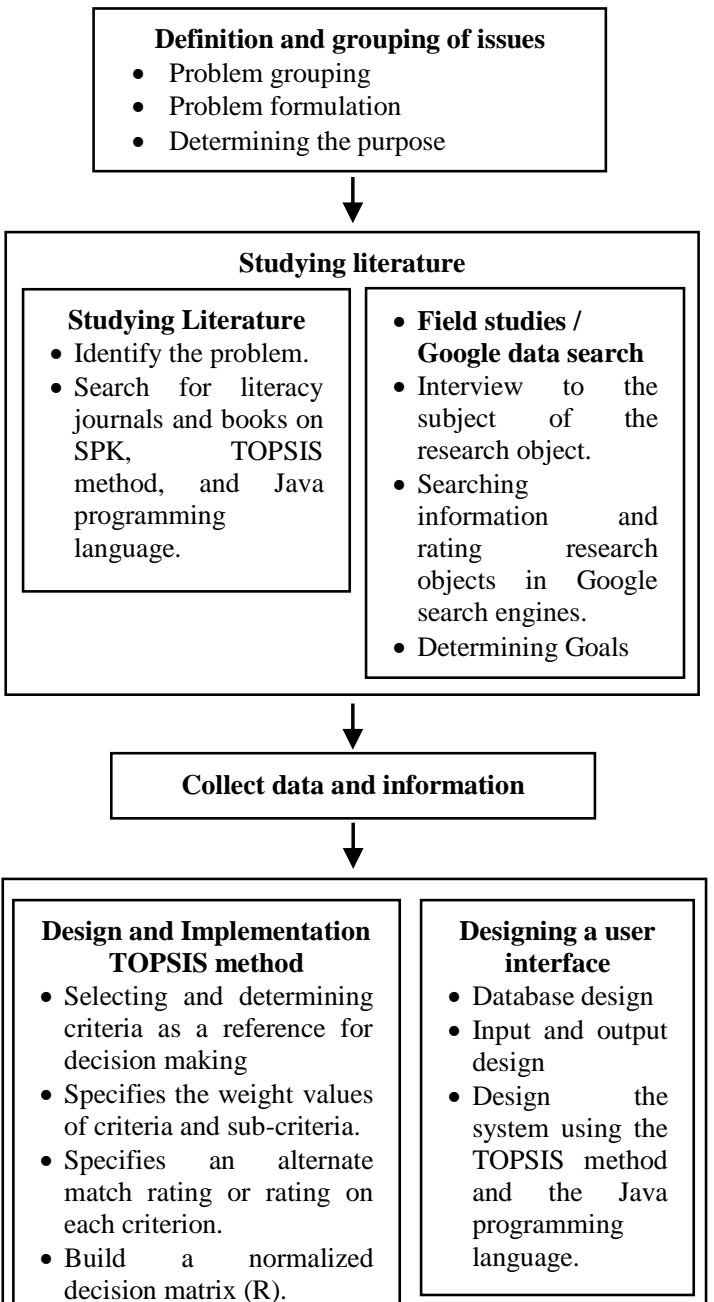


Figure 2: Research Framework

From the framework described above, it can be described the discussion of each activity as follows:

1. Defense and grouping problems

a. Problem Grouping.

The main thing that must be determined in defense segmentation and problem grouping is located when researchers want to select and group the problems to be researched because it can help researchers to focus and facilitate researchers on what problems to solve or create solutions.

b. Problem Formulation.

After the researcher's group the problem, then what must be done next is to formulation the problem by inserting it into the problem cluster table, so that several core items of the problem will be formed into the formulation of the problem.

c. Determining Goals

Based on the formulation of problems and hypotheses that have been made in the previous stage, the goal-setting stage is useful to clarify the framework of what is the target of this research.

2. studying Literature

In studying literature studies there are two stages, namely:

a. Conducting literature studies by starting from the completion of identification and grouping of problems, the thing to do is to look for literacy journals, proceedings, and books, Java Programming, and TOPSIS methods, it is useful to obtain references and literature that support the research process.

b. Conduct field studies/google data searches.

Field study/google data search that the author did on the object researched by:

a. Observation and interview, namely conducting a direct question and answer with one of the research subjects responsible for the management of research objects.

b. Searching information and rating research objects are the power and efforts of researchers to get information resources that can be processed as research materials to be more real and complex.

3. Collect and analyze data

The process of collecting and analyzing data was carried out with a team of researchers and the parts related to the running and smooth running of this research.

4. Design and Implementation of the TOPSIS method

Perform some steps of the TOPSIS method, and design the application using Java programming. Stages in the creation of the system are divided into several parts such as:

a. Database design 
Researchers designed a database design for the system that has been analyzed.

b. Output input design

In this section, the researchers proceed with making the design of system inputs and outputs in general.

c. Designing systems with TOPSIS methods and Java programming languages in detail.

d. System implementation

In the final stages, researchers began the development of applications using the Java programming language and TOPSIS method.

5. Development and Implementation

This stage is carried out a trial of the design results so that in the future TOPSIS method and Java programming designed can be made a ready-made application.

\section{System Evaluation Testing}

Test results are an evaluation of the system that has been designed to find out if the designed system is as expected.

\section{RESULTS AND DISCUSSIONS}

In determining the selection of Wali Nagari candidates using the TOPSIS method, the following is the discussion of the calculation.

1. Determination of the weight value of the criteria

\section{Table 1: Assessment Criteria}

\begin{tabular}{clc}
\hline Code & \multicolumn{1}{c}{ Criteria } & Weights \\
\hline K1 & Age & 2 \\
\hline K2 & Education & 4 \\
\hline K3 & Job & 3 \\
\hline K4 & Insights & 5 \\
\hline K5 & Health & 4 \\
\hline K6 & Income & 2 \\
\hline K7 & organization & 5 \\
\hline K8 & Domicile & 3 \\
\hline K9 & Gender & 2 \\
\hline K10 & Concern & 5 \\
\hline K11 & Legal status & 3 \\
\hline
\end{tabular}

The weight value is determined on a scale of 1-5 based on the level of importance of the criteria specified.

2. Sub-criteria weight value

To facilitate the calculation of assessment data, sub-criteria weight value using fuzzy logic can be seen in the following table:

Table 2: Sub Criteria Weight value

\begin{tabular}{|c|c|c|}
\hline Criteria & Sub-Criteria & Weights \\
\hline \multirow{6}{*}{ Age } & $25-29$ & 0,6 \\
\hline & $30-34$ & 0,7 \\
\hline & $35-39$ & 0,8 \\
\hline & $40-44$ & 1 \\
\hline & $45-49$ & 0,9 \\
\hline & $50-55$ & 0,5 \\
\hline \multirow{8}{*}{ Education } & Junior high school & 0,3 \\
\hline & High school & 0,4 \\
\hline & Diploma 1 & 0,5 \\
\hline & Diploma 2 & 0,6 \\
\hline & Diploma 3 & 0,7 \\
\hline & Strata 1 & 0,8 \\
\hline & Strata 2 & 0,9 \\
\hline & Strata 3 & 1 \\
\hline \multirow{11}{*}{ Job } & Unemployment & 0,1 \\
\hline & Fishing & 0,2 \\
\hline & Farmers & 0,2 \\
\hline & Employees & 0,3 \\
\hline & Police & 0,4 \\
\hline & Army & 0,4 \\
\hline & Teacher & 0,5 \\
\hline & Lecturer & 0,5 \\
\hline & civil servants & 0,5 \\
\hline & Self-employed & 0,3 \\
\hline & Entrepreneur & 0,3 \\
\hline \multirow{3}{*}{ Insights } & High & 1 \\
\hline & Medium height & 0,7 \\
\hline & Low & 0,4 \\
\hline \multirow{3}{*}{ Health } & Healthy & 1 \\
\hline & have been treated & 0,5 \\
\hline & $\begin{array}{l}\text { Defects of the five } \\
\text { senses }\end{array}$ & 0,2 \\
\hline \multirow{6}{*}{ Income } & $<1$ Million & 0,2 \\
\hline & $1-2$ Million & 0,3 \\
\hline & $>2-3$ Million & 0,4 \\
\hline & $>3-4$ Million & 0,5 \\
\hline & $>4-5$ Million & 0,6 \\
\hline & $>5$ Million & 0,7 \\
\hline \multirow[t]{2}{*}{ Organization } & $\begin{array}{l}\text { Active political } \\
\text { parties }\end{array}$ & 1 \\
\hline & Active community & 0,9 \\
\hline
\end{tabular}




\begin{tabular}{llc} 
& \multicolumn{1}{l}{ organizations } & \\
& $\begin{array}{l}\text { Active religious } \\
\text { organizations }\end{array}$ & 0,8 \\
& $\begin{array}{l}\text { Active indigenous } \\
\text { organizations }\end{array}$ & 0,7 \\
\cline { 2 - 3 } & $\begin{array}{l}\text { Active social } \\
\text { organization }\end{array}$ & 0,6 \\
\cline { 2 - 3 } & $\begin{array}{l}\text { Active youth } \\
\text { organizations }\end{array}$ & 0,5 \\
\cline { 2 - 3 } & $\begin{array}{l}\text { Inactive } \\
\text { organization }\end{array}$ & 0,2 \\
\hline \multirow{2}{*}{ Domicile } & Expat & 0,5 \\
\cline { 2 - 3 } & Native & 1 \\
\hline \multirow{2}{*}{ Gender } & Male & 1 \\
\cline { 2 - 3 } & Women & 0,5 \\
\hline \multirow{2}{*}{ Concern } & Very caring & 1 \\
\cline { 2 - 3 } & Care & 0,8 \\
\cline { 2 - 3 } & Less caring & 0,5 \\
\cline { 2 - 3 } Legal status & It doesn't matter & 0,1 \\
\cline { 2 - 3 } & Legal defects & 0,5 \\
\hline \multirow{2}{*}{ No legal defects } & 1 \\
\hline
\end{tabular}

Sub-criteria weight value using fuzzy logic is used to convert the data value of the Wali Nagari candidate before being used as a normalization matrix.

3. Calculation process using the TOPSIS method

The following calculation process with TOPSIS method steps are as follows: a. Input data on the criteria of Wali Nagari candidates' values and the weight of each sub-criterion that has been converted to fuzzy values such as the table below [16]:

Table 3: Data after converting

\begin{tabular}{cccccccccccc}
\hline \multirow{2}{*}{$\begin{array}{c}\text { Altern } \\
\text { atives }\end{array}$} & \multicolumn{10}{c}{ Fuzzy value } \\
\cline { 2 - 12 } & K1 & K2 & K3 & K4 & K5 & K6 & K7 & K8 & K9 & K10K11 \\
\hline A1 & 0,9 & 0,3 & 0,3 & 0,7 & 1 & 0,3 & 0,7 & 1 & 1 & 1 & 1 \\
\hline A2 & 0,9 & 0,8 & 0,5 & 0,7 & 1 & 0,3 & 0,7 & 1 & 1 & 0,5 & 1 \\
\hline A3 & 0,7 & 0,8 & 0,3 & 0,7 & 1 & 0,4 & 0,9 & 1 & 1 & 0,8 & 1 \\
\hline A4 & 0,6 & 0,9 & 0,3 & 0,7 & 1 & 0,3 & 0,8 & 1 & 1 & 0,8 & 1 \\
\hline A5 & 1 & 0,8 & 0,3 & 0,4 & 1 & 0,3 & 0,2 & 1 & 0,5 & 0,5 & 1 \\
\hline
\end{tabular}

b. Building matrices of normalized decisions of each category is denoted by $\mathrm{X}(\mathrm{i})$ where $\mathrm{i}=1,2,3$, and 4 . The formula of matric normalization is as follows [17]:

$$
r_{i j}=\frac{x_{i j}}{\sqrt{\sum_{i=1}^{m} x_{i j}^{2}}}
$$

where $I=1,2, \ldots, m$ and $\mathrm{j}=1.2, \ldots, \mathrm{n}$ then:
$X(1)=\sqrt{0,9^{2}+0,9^{2}+0,7^{2}+0,6^{2}+1^{2}}=3,47$

Then:

$$
\begin{gathered}
R(1,1)=\frac{0,9}{3,47}=0,26 \\
R(2,1)=\frac{0,9}{3,47}=0,26 \\
R(3,1)=\frac{0,7}{3,47}=0,20 \\
R(4,1)=\frac{0,6}{3,47}=0,17 \\
R(5,1)=\frac{1}{3,47}=0,29 \\
X(2)=\sqrt{0,3^{2}+0,8^{2}+0,8^{2}+0,9^{2}+0,8^{2}}
\end{gathered}
$$

Then:

$$
\begin{gathered}
R(1,2)=\frac{0,3}{2,82}=0,11 \\
R(2,2)=\frac{0,8}{2,82}=0,28 \\
R(3,2)=\frac{0,8}{2,82}=0,28 \\
R(4,2)=\frac{0,9}{2,82}=0,32 \\
R(5,2)=\frac{0,8}{2,82}=0,28 \\
X(3)=\sqrt{0,3^{2}+0,5^{2}+0,3^{2}+0,3^{2}+0,3^{2}} \\
=0,61
\end{gathered}
$$

Then:

$$
\begin{gathered}
R(1,3)=\frac{0,3}{0,61}=0,49 \\
R(2,3)=\frac{0,5}{0,61}=0,82 \\
R(3,3)=\frac{0,3}{0,61}=0,49 \\
R(4,3)=\frac{0,3}{0,61}=0,49 \\
R(5,3)=\frac{0,3}{0,61}=0,49 \\
X(4)=\sqrt{0,7^{2}+0,7^{2}+0,7^{2}+0,7^{2}+0,4^{2}}
\end{gathered}
$$

Then:

$$
\begin{aligned}
& R(1,4)=\frac{0,7}{2,12}=0,33 \\
& R(2,4)=\frac{0,7}{2,12}=0,33 \\
& R(3,4)=\frac{0,7}{2,12}=0,33
\end{aligned}
$$




$$
\begin{gathered}
R(4,4)=\frac{0,7}{2,12}=0,33 \\
R(5,4)=\frac{0,4}{2,12}=0,19 \\
X(5)=\sqrt{1^{2}+1^{2}+1^{2}+1+1^{2}}=5
\end{gathered}
$$

Then:

$$
\begin{aligned}
& R(1,5)=\frac{1}{5}=0,20 \\
& R(2,5)=\frac{1}{5}=0,20 \\
& R(3,5)=\frac{1}{5}=0,20 \\
& R(4,5)=\frac{1}{5}=0,20 \\
& R(5,5)=\frac{1}{5}=0,20
\end{aligned}
$$

To determine the value of $\mathrm{R}(1,6)$ to $\mathrm{R}(5,11)$ is done in the same way in the calculation above, then the following normalized decision matrix is processed:

$R$
$=\left[\begin{array}{lllllllllll}\mathbf{0}, 26 & \mathbf{0 , 1 1} & \mathbf{0 , 4 9} & \mathbf{0 , 3 3} & \mathbf{0 , 2 0} & \mathbf{0 , 5 8} & \mathbf{0 , 2 8} & \mathbf{0 , 2 0} & \mathbf{0 , 2 4} & \mathbf{0 , 3 6} & \mathbf{0 , 2 0} \\ \mathbf{0 , 2 6} & \mathbf{0 , 2 8} & \mathbf{0 , 8 2} & \mathbf{0 , 3 3} & \mathbf{0 , 2 0} & \mathbf{0 , 5 8} & \mathbf{0 , 2 8} & \mathbf{0 , 2 0} & \mathbf{0 , 2 4} & \mathbf{0 , 1 8} & \mathbf{0 , 2 0} \\ \mathbf{0 , 2 0} & \mathbf{0 , 2 8} & \mathbf{0 , 4 9} & \mathbf{0 , 3 3} & \mathbf{0 , 2 0} & \mathbf{0 , 7 7} & \mathbf{0 , 3 6} & \mathbf{0 , 2 0} & \mathbf{0 , 2 4} & \mathbf{0 , 2 9} & \mathbf{0 , 2 0} \\ \mathbf{0 , 1 7} & \mathbf{0 , 3 2} & \mathbf{0 , 4 9} & \mathbf{0 , 3 3} & \mathbf{0 , 2 0} & \mathbf{0 , 5 8} & \mathbf{0 , 3 2} & \mathbf{0 , 2 0} & \mathbf{0 , 2 4} & \mathbf{0 , 2 9} & \mathbf{0 , 2 0} \\ 0,29 & \mathbf{0 , 2 8} & \mathbf{0 , 4 9} & \mathbf{0 , 1 9} & \mathbf{0 , 2 0} & \mathbf{0 , 5 8} & \mathbf{0 , 0 8} & \mathbf{0 , 2 0} & \mathbf{0 , 1 2} & \mathbf{0 , 1 8} & \mathbf{0 , 2 0}\end{array}\right]$

c. Create a normalized weighted decision matrix (V) whose elements are determined from $\mathrm{R}(\mathrm{i})$. calculation of the normalized weighted decision matrix is as follows [18]:

$$
V_{i j}=W j \cdot R i j
$$

With $\mathrm{i}=1,2,3, \ldots, \mathrm{m}$; and $\mathrm{j}=1,2,3, \ldots$, $\mathrm{n}$; and $\mathrm{Wj}$ is the reference weight of each criterion. From the calculation results obtained a normalized weighted decision matrix is as follows:

$V=\left[\begin{array}{lllllllllll}0,52 & 0,44 & 1,47 & 1,65 & 0,80 & 1,16 & 1,40 & 0,60 & 0,48 & 1,80 & 0,60 \\ 0,52 & 1,12 & 2,46 & 1,65 & 0,80 & 1,16 & 1,40 & 0,60 & 0,48 & 0,90 & 0,60 \\ 0,40 & 1,12 & 1,47 & 1,65 & 0,80 & 1,54 & 1,80 & 0,60 & 0,48 & 1,45 & 0,60 \\ 0,34 & 1,28 & 1,47 & 1,65 & 0,80 & 1,16 & 1,60 & 0,60 & 0,48 & 1,45 & 0,60 \\ 0,58 & 1,12 & 1,47 & 0,95 & 0,80 & 1,16 & 0,40 & 0,60 & 0,24 & 0,90 & 0,60\end{array}\right]$

d. Determines the matrix of the positive ideal solution $(\mathrm{A}+)$ and the negative ideal solution (A-) [19].

Based on the results of matrix $V$ above, it can be prepared positive ideal solution $(\mathrm{A}+)$ and negative ideal solution (A-) as follows: \begin{tabular}{llllllllllll}
\hline $\mathbf{A}^{+}$ & 0,58 & 1,28 & 2,46 & 1,65 & 0,80 & 1,54 & 1,80 & 0,60 & 0,48 & 1,80 & 0,60
\end{tabular} \begin{tabular}{llllllllllll}
\hline $\mathbf{A}^{-}$ & 0,34 & 0,44 & 1,47 & 0,95 & 0,80 & 1,16 & 0,40 & 0,60 & 0,24 & 0,90 & 0,60
\end{tabular}

e. Calculates the separation or alternate distance from the positive ideal solution $(\mathrm{S}+)$ and the negative ideal solution (S-) [20].

Formula to calculate the alternative distance from the ideal positive solution, as follows:

$$
S_{i}^{+}=\sqrt{\sum_{j=1}^{n}\left(v_{i j}-v_{j}^{+}\right)^{2}}
$$

Formula to calculate the alternative distance from the negative ideal solution, as follows:

$$
\mathrm{S}_{i}^{-}=\sqrt{\sum_{j=1}^{n}\left(v_{i j}-v_{j}^{-}\right)^{2}}
$$

From the calculation results are obtained such as (distance) positive ideal solution and negative ideal solution distance as in the following table:

\begin{tabular}{cc}
\hline $\mathbf{S}^{+}$ & $\mathbf{S}^{-}$ \\
\hline 1,9937 & 2,39 \\
\hline 1,1436 & 3,0225 \\
\hline 1,1606 & 3,4205 \\
\hline 1,3446 & 2,9957 \\
\hline 4,4677 & 0,52 \\
\hline
\end{tabular}

f. Calculates the relative proximity of each alternative to the positive ideal solution $(\mathrm{Ci}+)$ [21].

The formula is as follows:

$$
c_{i}^{+} \frac{S_{i}^{-}}{\left(S_{i}^{-}+S_{i}^{+}\right)}
$$

From the results of the calculation of relative proximity of each alternative positive ideal solution $(\mathrm{Ci}+)$ as in the following table:

\begin{tabular}{cccc}
\hline $\mathbf{i}$ & $\mathbf{S}^{+}$ & $\mathbf{S}^{-}$ & $\mathbf{C}^{+}$ \\
\hline 1 & 1,9937 & 2,39 & 0,545201542 \\
\hline 2 & 1,1436 & 3,0225 & 0,725498668 \\
\hline 3 & 1,1606 & 3,4205 & 0,746654734 \\
\hline 4 & 1,3446 & 2,9957 & 0,690205746 \\
\hline 5 & 4,4677 & 0,52 & 0,104256471 \\
\hline
\end{tabular}

g. Alternate ranking [22].

\begin{tabular}{clccc}
\hline No & Alternatives & $\mathbf{S}^{+}$ & $\mathbf{S}^{-}$ & $\mathbf{C}^{+}$ \\
\hline 1 & A3 & 1,1606 & 3,4205 & 0,746654734
\end{tabular}




\begin{tabular}{lllcc}
2 & A2 & 1,1436 & 3,0225 & 0,725498668 \\
3 & A4 & 1,3446 & 2,9957 & 0,690205746 \\
4 & A1 & 1,9937 & 2,39 & 0,545201542 \\
5 & A5 & 4,4677 & 0,52 & 0,104256471 \\
\hline
\end{tabular}

\section{Testing}

To prove the truth at the stage of analysis and design of the system, it is necessary to conduct testing to recommend the choice of the best guardian candidates with the method Technique For Order Preference by Similarity to Ideal Solution (TOPSIS):

a. The view of the input page of the assessment data of Wali Nagari candidates.

This view shows each data of prospective guardians will be input into the system based on the assessment criteria that have been determined, the data of each prospective guardian has been recaptured by the KPPS, and there are several data here each individual chooses based on the assessment criteria to the prospective guardian, such as age, education, employment, insight, health, income, organization, domicile, gender, care, legal status.

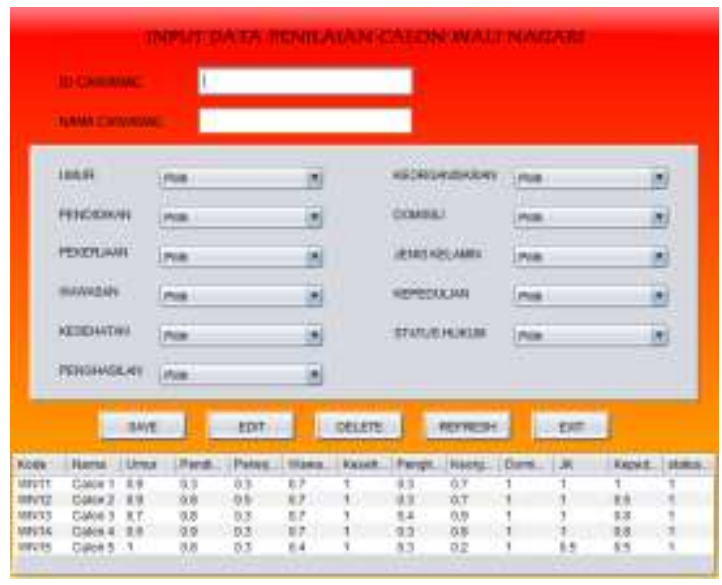

Figure 3: View the input page of the assessment data of prospective trustees

b. Step-by-step process page view with TOPSIS method

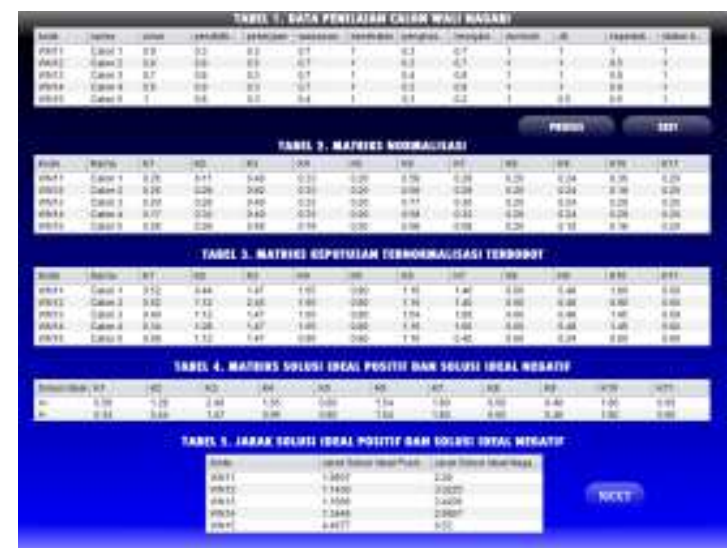

Figure 4: Page view of TOPSIS method calculation steps

c. Ranking pageview

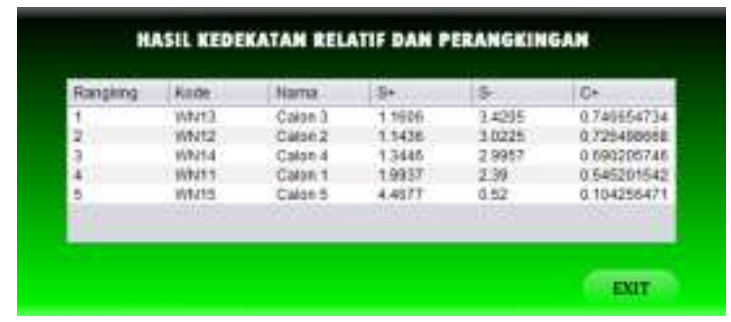

Figure 5: Ranking page view.

d. Ranking report view

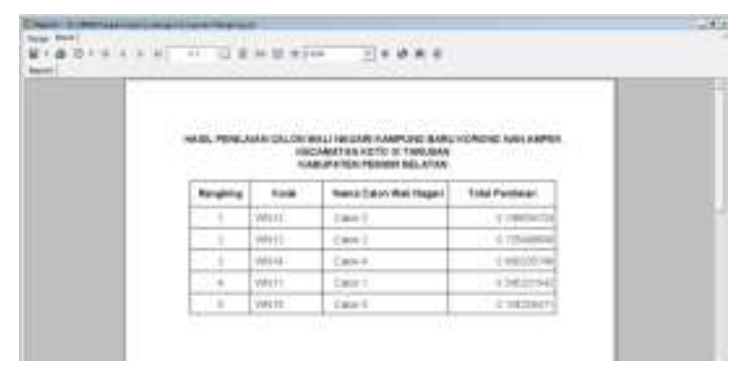

Figure 6: Ranking report.

\section{CONCLUSION}

Based on the results of this research, it can be concluded that the decision support system built can provide recommendations to the local community in the selection of guardian candidates quickly and accurately. By applying the TOPSIS method used in the calculation process can process the data accurately and precisely starting with determining the criteria of the variables used, then 
creating a matrix and continued on the matrix process of positive ideal solutions and ideal negative solutions and stages of working. The results obtained in the study also provide a model or form of a semistructured system in the selection of guardian candidates using a system of supporting TOPSIS method decisions. So that the benefit will be able to provide recommendations for the public to choose the candidates for trustees appropriately and accurately.

\section{REFERENCES}

[1] D. Aromatica, H. Nurasa, I. Widianingsih, and E. A. Muhtar, "Analisis Kelembagaan Pemerintahan Nagari di Kabupaten Solok Provinsi Sumatera Barat," JPPUMA J. Ilmu Pemerintah. dan Sos. Polit. Univ. Medan Area, vol. 6, no. 2, p. 156, 2018, doi: 10.31289/jppuma.v6i2.1828.

[2] H. Setiawan, "Dilematika Sistem Pemerintahan Nagari Dalam Kehidupan Masyarakat Etnis Mandailing," Nusant. J. Ilmu Pengetah. Sos., vol. 6, no. 1, p. 41, 2019, doi: 10.31604/jips.v6i1.2019.41-50.

- R. and R. Herawati, "PEMILIHAN KEPALA DESA SERENTAK DALAM PERSPEKTIF OTONOMI DESA (Studi Kasus Pelaksanaan Pemilihan Kepala Desa Serentak Tahun 2016 di Kabupaten Rokan Hilir, Provinsi Riau)," $L A W$ REFORM, 2017, doi: 10.14710/lr.v13i1.15956.

[4] M. Irham and M. Soplanit, "Pemilihan Kepala/Wali

Desa/Nagari Dengan Sistem EVoting Di Kabupaten Agam
Provinsi Sumatera Barat," SASI, 2018 , doi: 10.47268/sasi.v23i2.106.

[5] R. R. Harahap, "PERILAKU POLITIK MASYARAKAT DALAM PEMILIHAN UMUM (PEMILU) LEGISLATIF KABUPATEN (Studi Kecamatan Dayun, Dapil II Kabupaten Siak, Tahun 2014)," Jom FISIP, 2016.

[6] M. Marbun and B. Sinaga, "Sistem Pendukung Keputusan Penilaian Hasil Belajar Mahasiswa dengan Metode Topsis di STMIK Pelita Nusantara Medan," J. Mantik Penusa, 2017.

[7] M. B. Anand and S. Vinodh, "Application of fuzzy AHP TOPSIS for ranking additive manufacturing processes for microfabrication," Rapid Prototyp. J., 2018, DOI: 10.1108/RPJ-102016-0160.

[8] P. A. W. Santiary, P. I. Ciptayani, N. G. A. P. H. Saptarini, and I. K. Swardika, "Sistem Pendukung Keputusan Penentuan Lokasi Wisata dengan Metode Topsis," J. Teknol. Inf. dan Ilmu Komput., 2018 , doi: 10.25126/jtiik.2018551120.

[9] S. D. Saputri and E. Ermatita, "Credit Scoring Kelayakan Debitur Menggunakan Metode Hybrid ANN Backpropagation dan TOPSIS," J. RESTI (Rekayasa Sist. dan Teknol. Informasi), 2019, doi: 10.29207/resti.v3i1.847.

[10] Dicky Nofriansyah dan Sarjon Defit, "Multi Criteria Decision Making (MCDM) pada Sistem Pendukung Keputusan," in Journal of Chemical Information and 
Modeling, 2017.

[11] F. Hadi and D. Guswandi, "Penentuan Penerimaan Mahasiswa Baru Pascasarjana Menggunakan Simple Additive Weighting (SAW)," Indones. J. Comput. Sci., 2019, doi: 10.33022/ijcs.v8i2.175.

[12] D. Nofriansyah, "Konsep Data Mining Vs Sistem Penunjang Keputusan," Deepublish. 2015.

[13] T. Limbong et al., Sistem Pendukung Keputusan Metode \& Implementasi. 2020.

[14] C. Surya, "Penilaian Kinerja Dosen Menggunakan Metode TOPSIS (Studi Kasus : Amik Mitra Gama)," J. RESTI (Rekayasa Sist. dan Teknol. Informasi), vol. 2, no. 1, pp. 322-329, 2018, doi: 10.29207/resti.v2i1.119.

[15] D. Arbian, "Sistem Pendukung Keputusan (SPK) Pemberian Beasiswa Berbasis TOPSIS (Studi Kasus Yayasan Pendidikan AlHikmah Bululawang Malang)," J. Ilm. Teknol. Inf. Asia, 2017, doi: 10.32815/jitika.v11i1.40.

[16] H. Ardiansyah, "Sistem Penunjang Keputusan Pemilihan Guru Terbaik dengan Metode TOPSIS (Technique for Order Preference by Similarity to Ideal Solution) Studi Kasus: SDN Bendungan Hilir 01 Pagi Jakarta Pusat," J. Inform. Univ. Pamulang, 2017, doi: 10.32493/informatika.v2i2.1510.

[17] G. Wibisono, A. Amrulloh, and E. Ujianto, "PENERAPAN METODE TOPSIS DALAM PENENTUAN DOSEN TERBAIK," Ilk. J. Ilm., 2019 , doi: 10.33096/ilkom.v11i2.430.102-
109.

[18] A. Rahmayani and M. I. Irawan, "Perancangan dan Implementasi Perangkat Kriteria Menggunakan Metode TOPSIS," J. Sains Dan Seni Its, 2016.

[19] E. G. Wahyuni and A. T. Anggoro, "Sistem Pendukung Keputusan Penerimaan Pegawai dengan Metode TOPSIS," Sains Teknol. dan Ind., 2017.

[20] V. V. Wang, A. S. Sukamto, and E. E. Pratama, "Sistem Pendukung Keputusan Seleksi Mahasiswa Penerima Beasiswa BBP-PPA dengan Metode TOPSIS pada Fakultas Teknik UNTAN," J. Sist. dan Teknol. Inf., 2019, doi: 10.26418/justin.v7i2.29656.

[21] I. Irianto, "PEMILIHAN PERUSAHAAN JASA PENGIRIMAN BARANG TERBAIK MENGGUNAKAN METODE TOPSIS,” J. Teknol. Inf., 2017, doi: 10.36294/jurti.v1i1.46.

[22] A. P. Dewi and R. Ariyanto, "PENGEMBANGAN SISTEM PENDUKUNG KEPUTUSAN UNTUK PENENTUAN PENERIMA BANTUAN RASKIN DENGAN MENGGUNAKAN METODE TOPSIS," J. Inform. Polinema, 2017, doi: 10.33795/jip.v2i1.49. 